\title{
Renal aspects of peptic ulcer pharmacology
}

\author{
Daniel Muruve, MD, Ellen Burgess, MD, FRCPC, FACP
}

D MURUVE, E BURGESs. Renal aspects of peptic ulcer pharmacology. Can J Gastroenterol 1992;6(1):29-34. Medications to treat peptic ulcer disease are used widely and may have adverse effects on renal function. Similarly, renal dysfunction may alter the pharmacokinetics of this diverse group of medications resulting in dosage adjustments. The older agents, antacids and sucralfate, allow absorption of cations (calcium, magnesium and aluminum) which may result in toxicity. Newer medications ( $\mathrm{H}_{2}$ blockers and omeprazole) appear to have fewer side effects and be better tolerated with appropriate dosage adjustments.

Key Words: Duodenal ulcer, Peptic ulcer, Renal pharmacology

\section{Aspect rénal de la pharmacologie de l'ulcère gastroduodénal}

RESUME: Les antiulcéreux sont largement prescrits et peuvent avoir des effets indésirables sur la fonction rénale. Pareillement, le dysfonctionnement rénal peut altérer la pharmacocinétique de ce groupe de médicaments divers et nécessiter l'ajustement de la posologie. Les médicaments plus anciens tels que les antiacides et le sucralfate permettent l'absorption des cations (calcium, magnésium et aluminium) et comportent des risques de toxicité. Administrés à des doses appropriées, les médicaments plus récents (antihistaminiques $\mathrm{H}_{2}$ et oméprazole) semblent causer des effets secondaires moindres et être mieux tolérés.

\section{T} HERE HAS BEEN AN INCREASE IN the number and classes of medications used to treat peptic ulcer and related diseases over the past 15 years. Most of these medications are relatively free from significant adverse effects and widely prescribed in clinical practice.

Patients with chronic renal failure have an increased incidence of upper gastrointestinal bleeding which may be related to acid hypersecretion $(1,2)$ or disturbances in serum gastric concentration or the mucosal barrier (3). Patients undergoing renal transplantation have a high incidence of postoperative gastrointestinal complications including gastritis and peptic ulceration due to factors including underlying

Department of Medicine, University of Calgary, Calgary, Alberta

Correspondence and reprints: Dr Ellen Burgess, 1403-29th Street NW, Calgary, Alberta

T2N 2 T9

Received for publication September 25, 1991. Accepted January 31, 1992

chronic renal failure, stress and steroid therapy $(4,5)$. Certain medications designed to treat peptic ulcer disease have different applications in the renal patient, eg, using antacids as phosphate binders and prostaglandin analogues in renal transplantation.

This article reviews the nephrological aspects of peptic ulcer pharmacology, focusing on adverse effects on the kidneys and pharmacokinetic changes produced by renal insufficiency.

\section{$\mathrm{H}_{2}$ BLOCKERS}

There are four $\mathrm{H}_{2}$ blockers available in Canada: cimetidine, ranitidine, famotidine and nizatidine - all equally effective in treating peptic ulcer disease (6). All of the $\mathrm{H}_{2}$ blockers are cleared primarily by the kidneys as unchanged drug. Following intravenous administration, 50 to $80 \%$ of the dose of cimetidine (7), $70 \%$ of ranitidine (8) and famotidine (9) and $75 \%$ of nizatidine $(10,11)$ is eliminated unchanged in the urine. Renal clearance of $\mathrm{H}_{2}$ blockers greatly exceeds the glomerular filtration rate consistent with active tubular secretion of the drugs which are all weak bases at physiological $\mathrm{pH}$; this tubular secretion may be via an organic cation secretory mechanism in the proximal tubule (12).

Renal insufficiency, therefore, results in decreased plasma clearance 
TABLE 1

Dose reduction recommended for peptic ulcer drugs in patients with renal insufficiency

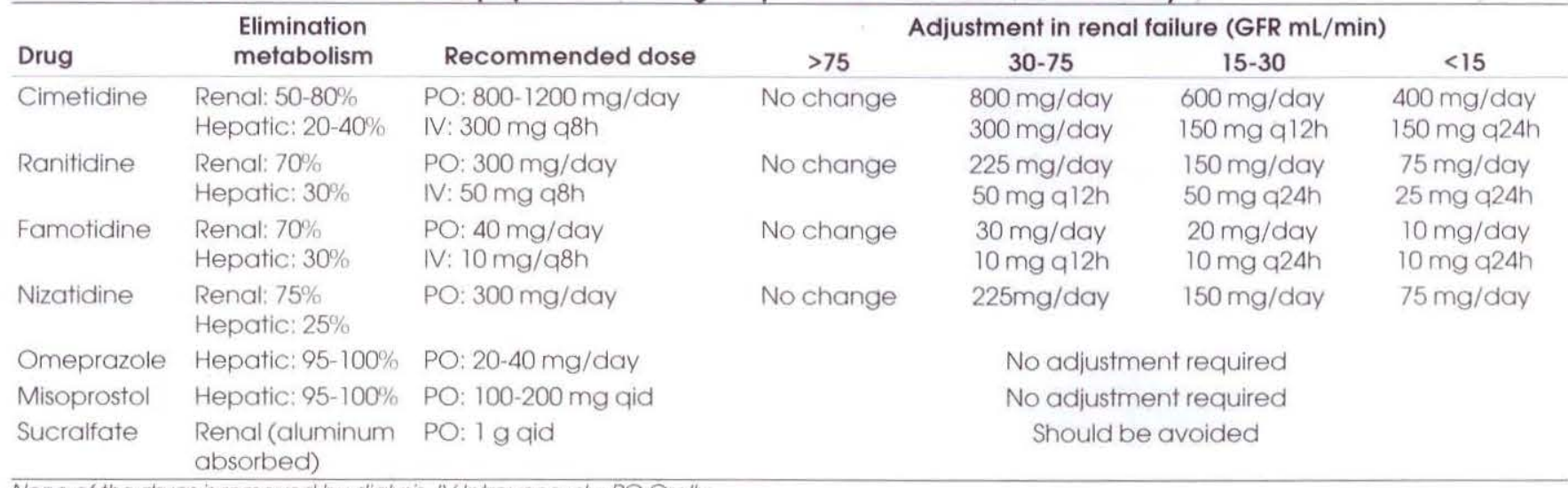

None of the drugs is removed by dialysis. IV Intravenously: PO Orally

and increased elimination half-life of all four medications (7,13-18). Drug accumulation can occur, leading to adverse effects - particularly central nervous system toxicity and mental confusion (19-21). Dose reduction is recommended for $\mathrm{H}_{2}$ blockers based on creatinine clearance (Table 1). All medications are minimally cleared by dialysis (both hemodialysis and peritoneal dialysis) and do not need to be supplemented post dialysis $(7,15,22,23)$.

Cimetidine, the first and prototypical $\mathrm{H}_{2}$ blocker, has several direct and indirect renal effects; it has been shown to inhibit competitively the tubular secretion of cations such as creatinine (thereby affecting creatinine-dependent measurements of renal function) and numerous basic drugs in the proximal tubule. It was first demonstrated by Burgess et al (24) to decrease renal creatinine clearance without affecting renal function as measured by inulin clearance. Cimetidine was also shown to decrease renal clearance of procainamide and its active metabolite, $\mathrm{N}$-acetylprocainamide (25); this inhibition of cationic tubular transport was confirmed in the isolated rabbit proximal tubule model by McKinney and Speeg (26). Cimetidine has also been shown to reduce the renal clearance of triamterene (27), metformin (28) and flecainide (29), presumably via the same mechanism.

These interactions with cimetidine are clinically significant because a decrease in drug clearance may lead to an increase in adverse effects, especially in the elderly and those with impaired renal function.

Numerous cases of acute interstitial nephritis have been reported with cimetidine therapy (30-34). Renal biopsies of such cases showed typical features of interstitial nephritis with infiltrates consisting of plasma cells, lymphocytes and eosinophils. Renal function in all patients improved over two to four weeks upon stopping the drug. Prednisone was used in several cases with apparent benefit.

Concerning the safety of cimetidine in renal transplantation, there were early reports of increased allograft rejection with cimetidine use (35); a study by Gifford and Tilberg (36) demonstrated that cimetidine reduced cyclosporine-mediated inhibition of iterleukin- 2 and therefore affected immunosuppression. However, the majority of studies using cimetidine as gastrointestinal prophylaxis in renal transplant recipients have shown no increase in rejection (37-41) or decrease in graft survival $(39,40)$. Therefore cimetidine appears to be safe for use in renal transplantation.

Like cimetidine, ranitidine is secreted by the proximal tubule and competitively inhibits the cationic secretory mechanism, but is five to eight times more potent than cimetidine with no known direct renal side effects or reports it causes acute interstitial nephritis (unlike cimetidine). Procainamide and $\mathrm{N}$-acetylprocainamide renal clearance is reduced by ranitidine, especially at high doses (42). However, the effect is minimal at therapeutic doses. In a select group of patients, such as the elderly and those with renal insufficiency, a reduction in procainamide dosage may be necessary when given concomitantly with ranitidine. Ranitidine has no influence on plasma (or serum) creatinine levels (42).

Famotidine is at least twenty times more potent than cimetidine and does not appear to inhibit the proximal tubule's cationic transport system at therapeutic doses. Famotidine has no effect on the renal clearance of procainamide (43) or tubular secretion of creatinine (44) and thus does not affect creatinine-dependent measurements of renal function. There are no reported cases of acute interstitial nephritis with famotidine.

Nizatidine is similar to ranitidine in potency. It has no known direct adverse effects on kidneys and is secreted in the proximal tubule. No studies regarding its effect on cationic secretion have been performed. Its metabolite $\mathrm{N}_{2}$. monodesmethyl-nizatidine is $60 \%$ as active as the parent drug and is excreted primarily by the kidneys (45).

\section{OMEPRAZOLE}

Omeprazole, a substituted benzimidazole, is the most potent inhibitor of gastric acid secretion available. Its mechanism of action is direct irreversible inhibition of $\mathrm{H}^{+}, \mathrm{K}^{+}$-ATPase, the gastric proton pump, in the parietal cell. Omeprazole is the most effective peptic ulcer therapy when evaluated at two and four weeks of treatment (6) with 
healing rates equivalent to other peptic ulcer medications at six weeks.

Omeprazole is rapidly and completely metabolized by the liver with insignificant amounts of unchanged drug present in the urine. However, approximately $80 \%$ of an intravenous and oral dose is excreted as metabolites via the kidney while the remainder is excreted in the stool (11). These metabolites, of which there are at least six, are not known to have any pharmacological activity.

Renal impairment has no effect on the pharmacokinetic profile of omeprazole because of its metabolism by the liver. However, the elimination of metabolites is significantly decreased during renal insufficiency and the percentage recovered in the urine is correlated with creatinine clearance (46). In the presence of renal impairment, total body clearance is complete approximately four days after a single dose, suggesting that metabolites are excreted by alternative methods. No alterations in dose or interval are required in renal failure.

Omeprazole is not known to affect the kidney directly. It has been shown not to affect urinary acidification or renal handling of electrolytes (47) consistent with a specific effect of omeprazole on parietal cells.

\section{SUCRALFATE}

Sucralfate is a basic aluminum salt of sucrose octasulfate effective in the treatment of peptic ulcer disease (48) with very few adverse effects; however, special consideration is needed in patients with renal failure.

Sucralfate contains significant amounts of aluminum which is absorbed and results in raised serum aluminum levels in subjects with normal renal function $(49,50)$. Aluminum is rapidly cleared by the kidneys and serum levels quickly return to baseline once therapy is stopped. Daily urinary excretion remains elevated for at least 10 days after discontinuation of a short course of therapy (49).

In patients with impaired renal function, significant increases in serum aluminum concentration and urinary aluminum excretion occur in patients receiving therapeutic doses of sucralfate (51). Elimination half-life of aluminum is prolonged in renal insufficiency (51) and aluminum accumulation may occur in patients who receive long term sucralfate therapy. Sucralfate has been demonstrated to reduce effectively phosphate levels in chronic renal failure compared to aluminum hydroxide $(52,53)$. However, similar aluminum absorption occurs with both medications, precluding the use of sucralfate as an alternative phosphate binder in chronic renal failure. Aluminum toxicity from sucralfate therapy manifested by dementia, renal osteodystrophy and anemia has been reported $(54-56)$. Sucralfate should be used with caution or avoided in patients with renal insufficiency.

\section{PROSTAGLANDINS}

Prostaglandins have numerous effects on the gastrointestinal tract, inhibiting basal gastric acid secretion and secretion stimulated by food and histamine in the stomach (57), they exert a trophic action on the gastric mucosa (58) and increase bicarbonate secretion (59), mucus production and mucosal bloodflow $(60,61)$. Prostaglandin $\mathrm{E}_{2}$ has been shown to inhibit histamine stimulated acid secretion by inhibiting adenylate cyclase via the inhibitory GTP binding protein and decreasing cyclic AMP production (62). In the kidney, prostaglandins E, D and I reportedly increase renal bloodflow and redistribute flow to the inner cortex (63).

Misoprostol is a synthetic prostaglandin $\mathrm{El}_{\mathrm{l}}$ analogue that has been demonstrated to reduce the volume and concentration of stomach acid (64). Its short half-life, frequent side effects and diarrhea have limited its use in clinical practice, although it has been proven effective in treating peptic ulcer disease (65) and is probably the most effective agent for preventing gastropathy caused by nonsteroidal anti-inflammatory drugs (66). Enprostil is a synthetic prostaglandin $E_{2}$ analogue with similar properties to misoprostol (67). Misoprostol is well absorbed and undergoes extremely rapid de-esterification to the biologically active metabolite, misoprostol acid, prior to or during absorp- tion. No unchanged drug is found in the urine. Misoprostol acid has a very short half-life and is rapidly metabolized to a number of metabolites which are excreted primarily by the kidneys (68). Only 1 to $4 \%$ of misoprostol acid is found intact in the urine. Renal insufficiency does not change the pharmacokinetic profile of misoprostol to any great extent and thus dosage change is not required in renal failure (69).

Several studies in rats, evaluating the use of misoprostol in renal transplantation, have demonstrated that it reverses or reduces acute cyclosporine toxicity in the kidney $(70,71)$, with reversal of the cyclosporine-induced acute renal vasoconstriction and decreased glomerular filtration rate. Ryffel et al (72) demonstrated a protective effect of misoprostol against cyclosporine nephrotoxicity, but also found that misoprostol reduced the bioavailability of cyclosporine (and thus decreased serum levels) and possibly interfered with the immunosuppressive effect of cyclosporine. However, prostaglandin E has been shown to prevent rejection in rat renal allograft recipients (73).

A recent double-blind placebo controlled study by Moran et al (74) evaluated the effect of misoprostol in renal transplant recipients treated with cyclosporine and prednisone; they concluded misoprostol reduced the acute rejection incidence in renal transplant patients. There was no statistically significant difference in acute cyclosporine nephrotoxicity between the treated and placebo groups, although nephrotoxicity tended to be higher in the misoprostol-treated patients.

The results of these studies demonstrate a possible role for misoprostol and other prostaglandin analogues in renal transplantation, but further studies are required before regular use can be advocated.

\section{ANTACIDS}

Prior to the development of newer drugs to treat peptic ulcer disease, antacids were the drug of choice, Their mode of action primarily is by neutralizing acid and increasing intragastric $\mathrm{pH}$ (although aluminum containing antacids may also be cytoprotective) (75). 
When used properly, antacids are effective in healing peptic ulcers.

There are several kinds of antacids; the majority are composed of aluminum, magnesium, calcium and/or sodium bicarbonate. In general, the major side effects are related to intestinal absorption of their constituents. Calcium, magnesium and aluminum containing antacids all undergo significant gastrointestinal absorption and are excreted mainly by the kidneys. In patients with impaired renal function, elimination of these cations is reduced; with protracted antacid use accumulation occurs, leading to hypercalcemia $(76,77)$, hypermagnesemia $(78,79)$ and hyperaluminemia $(80,81)$.

Many other adverse effects can result from excessive antacid use such as nephrolithiasis (82), metabolic alkalosis (83) and the 'milk-alkali syndrome' (82-84). The milk-alkali syndrome consists of hypercalcemia, metabolic alkalosis and renal failure, and is associated with ingestion of large quantities of calcium (as milk or calcium containing antacids) and alkali (antacids). Symptoms include nausea, vomiting, anorexia, polyuria and polydipsia. The condition has become quite

\section{REFERENCES}

1. Shepherd AMM, Stewart WK, Wormsley KG. Pepric ulceration in chronic renal failure. Lancet 1973;i:1357-9

2. Wormsley KG. Association between duodenal ulcer and other diseases. Scand I Gastroenterol 1980;15(Suppl):27-35.

3. Peltekian KM, Handa SP. Gastric abnormalities in chronic renal failure. Ann RCPSC 1991;24:58-60.

4. Hadjiyannakis E], Evans DB, Smellie WAB, Calne RY. Gastrointestinal complications after renal transplantation. Lancet 1971;ii:781-5.

5. Owens ML, Passaro E, Wilson SE, Gordon HE. Treatment of peptic ulcer disease in the renal transplant patient. Ann Surg 1977;186:17-21.

6. Molina F, Vohra MM, Williams CN. Pharmacotherapy of peptic ulcer disease. Can J Gastroenterol 1991;5:21-33.

7. Somogyi A, Gugler R. Clinical pharmacokinetics of cimetidine. Clin Pharmacokinet 1983;8:463-95.

8. Garg DC, Weidler DJ, Eshelman FN. Ranitidine bioavailability and kinetics in normal male subjects. Clin uncommon with the advent of modern therapy for peptic ulcer disease. Patients with underlying renal disease are more susceptible to the milk-alkali syndrome; its pathogenesis is unclear, but it is thought to be due to prolonged hypercalcemia, secondary to increased absorption and decreased renal excretion of calcium with subsequent compromised tubular dysfunction and nephrocalcinosis (85). The alkalosis is due to excessive alkali absorption and vomiting, leading to volume contraction which further exacerbates hypercalcemia and renal failure. Soft tissue calcification can also occur. Treatment with intravenous fluids, furosemide and a low-calcium diet is directed at hypercalcemia.

Aluminum hydroxide was the phosphate binder of choice for many years in hyperphosphatemia treatment in chronic renal failure. After it was demonstrated that aluminum absorption and toxicity occurred $(80,81)$, causing encephalopathy and bone disease, alternative phosphate binders were sought. Calcium carbonate has emerged as the new agent to control hyperphosphatemia. Several studies have demonstrated the efficacy of lowering serum

Pharmacol Ther 1983;33:445-54.

9. Kroemer H, Klotz U. Pharmacokinetics of famotidine in man. Int J Clin

Pharmacol Ther Toxicol 1987:25:458.63

10. Callaghan IT, Bergstrom RF, Rubin A, et al. A pharmacokinetic profile of nizatidine in man. Scand ] Gastroenterol 1987;136(Suppl):9-12.

11. Regardh CG. Pharmacokinetics and metabolism of omeprazole in man. Scand I Gastroenterol 1986;118(Suppl):99-104.

12. Rennick BR. Renal tubule transport of organic cations. Am J Physiol 1981;240:F83-9.

13. Takabatake T, Ohta H, Maekawa M, et al. Pharmacokinetics of famotidine, a new $\mathrm{H}_{2}$-receptor antagonist in relation to renal function. Eur J Clin Pharmacol 1985;28:327-31.

14. Halstenson CE, Abraham PA, Ospsahl JA, Chremos AN, Keane WF, Matzke GR. Disposition of famotidine in renal insufficiency. J Clin Pharmacol 1987:27:782-7.

15. Aronoff GR, Bergstrom RF, Bopp RJ, Sloan RS, Callaghan JT. Nizatidine disposition in subjects with normal and impaired renal function. Clin phosphate levels using oral calcium carbonate without the risk of aluminum toxicity $(76,77,86)$. One-quarter of patients receiving calcium carbonate develop mild hypercalcemia which resolves upon stopping the drug or with use of low-calcium dialysate. Risk concerning metastatic calcinosis (such as corneal, conjunctival, subcutaneous, periarticular) with long term calcium carbonate therapy has never been fully evaluated and thus serum calcium levels should be followed.

Antacids are readily available and may produce a variety of adverse effects especially in the patient with diminished renal function. Aluminum containing antacids should be avoided in patients with renal failure due to the risk of developing aluminum accumulation and toxicity.

Peptic ulcer medications are widely used in clinical practice and have many gastrointestinal and nongastrointestinal applications in patients with renal disease. Generally, antacids are safe with very few renal side effects. However, certain precautions do exist and some medications should be used with caution or avoided in patients with renal failure.

Pharmacol Ther 1988;43:688-95.

16. Garg DC, Baltodano N, Jallad NS, et al. Pharmacokinetics of ranitidine in patients with renal failure. J Clin Pharmacol 1986;26:286-91.

17. Meffin PJ, Grgurinovich N, Brooks PM, Miners JO, Cochran M, Stranks G. Ranitidine disposition in patients with renal impairment. $\mathrm{Br} J$ Clin Pharmacol 1983; 16:731-4

18. McFadyen ML, Folb PI, Miller R, Keeton GR, Marks IN.

Pharmacokinetics of ranitidine in patients with chronic renal failure. Eur J Clin Pharmacol 1983;25:347-51.

19. Schentag JJ, Cerra FB, Calleri G, DeGlopper E, Rose 1Q, Bernhard H. Pharmacokinetic and clinical studies in patients with cimetidine associated mental confusion. Lancet $1979 ; \mathrm{i}: 177-81$

20. Henann NE, Carpenter DU, landa SM. Famotidine associated mental confusion in elderly patients. Drug Intell Clin Pharm 1988;22:976-8.

21. Sommenblick M, Yinnan A. Mental confusion as a side effect of ranitidine Am J Psych 1986;143:257.

22. Garg DC, Baltodano N, Jallad NS, et al. Pharmacokinetics of ranitidine 
after intravenous administration in hemodialysis patients. Pharmacology 1985;31:189-93.

23. Gladziwa U, Klotz U, Krishna DR, Schmitt H, Glöckner WM, Mann H. Pharmacokinetic and dynamics of famotidine in patients with renal failure. Br J Clin Pharmacol 1988;26:315-21.

24. Burgess E, Blair A, Kirchman K, Cutler $R E$. Inhibition of renal creatinine secretion by cimetidine in humans. Renal Physiol 1982;5:27-30.

25. Somogyi A, McLean A, Heinzow B. Cimetidine procainamide pharmacokinetic interaction in man: Evidence of competition for tubular secretion of basic drugs. Eur $]$ Clin Pharmacol 1983;25:339-45.

26. McKinney TD, Speeg KV. Cimetidine and procainamide secretion by proximal tubules in vitro. Am J Physiol 1982;242:F672-80.

27. Muirhead MR, Somogyi A, Rolan PE, Bochner F. Effect of cimetidine on renal and hepatic drug elimination: Studies with triamterene. Clin Pharmacol Ther 1986;40:400-7.

28. Somogyi A, Stockley C, Keal J, Rolan $\mathrm{P}$, Bochner F. Reduction of metformin renal tubular secretion by cimetidine in man. Br J Clin Pharmacol 1987;23:545-51.

29. Tjandra Maga BT, Verbesselt R, Van Hecken A, VanMelle P, DeSchepper PJ. Oral flecainide kinetics: Effects of cimetidine. Circulation 1983;68 (Suppl 3):III-416. (Abst)

30. McGowan WR, Vermillion SE. Acute interstitial nephritis related to cimetidine therapy. Gastroenterology 1980;79:746-9.

31. Handa PS. Drug induced interstitial nephritis: Report of ten cases. Can Med Assoc J 1986;135:1278-81.

32. Kaye WA, Passero MA, Soloman RJ, Johnson LA. Cimetidine induced interstitial nephritis with response to prednisone therapy. Arch Intern Med 1983;143:811-2.

33. Richman AV, Narayan JL, Hirschfield JSD. Acute interstitial nephritis and acute renal failure associated with cimetidine therapy. Am J Med 1981;70:1272-4.

34. Rudnick MR, Bastl CP, Elfenbein IB, Sirota RA, Yudis M, Narins RG. Cimetidine-induced acute renal failure. Ann Intern Med 1982;96:180-2.

35. Primack WA. Cimetidine and renal allograft rejection. Lancet $1978 ; i: 824$.

36. Gifford RRM, Tilherg MS. Cimetidine reduces cyclosporine inhibition of interleukin-2 production. J Surg Res 1988;45:276-80.

37. Pachon J, Lorber MI, Bia MJ. Effects of $\mathrm{H}_{2}$-receptor antagonists on renal function in cyclosporine-treated renal transplant fatients. Transplantation 1989;47:254-9.

38. Doherty CC, McGeown MG. Cimetidine and renal allograft rejection. Lancet 1978; i: 1048.

39. Van Roermund HPC, Tiggeler RGWL, Berden JHM, Van Lier HJJ, Koene RAP. Cimetidine prophylaxis after renal transplantation. Clin Nephrol 1982;18:39-42.

40. Grekas D, Theocharides A, Nakos V, Spanos P, Arvanitakis C, Tourkantonis A. Prophylactic treatment with cimetidine after renal transplantation. Nephron 1985;40:213-5.

41. Walter S, Andersen JT, Christensen $\mathrm{U}$, et al. Effect of cimetidine on upper gastrointestional bleeding after renal transplantation: A prospective study. Br Med J 1984;289:1175-6.

42. Somogyi A, Bochner F. Dose and concentration dependent effect of ranitidine on procainamide disposition and renal clearance in man. $\mathrm{Br}]$ Clin Pharmacol 1984; 18:175-81.

43. Klotz U, Arvela P, Rosenkranz B. Famotidine, a new $\mathrm{H}_{2}$-receptor antagonist, does not affect hepatic elimination of diazepam or tubular secretion of procainamide. Eur J Clin Pharmacol 1985;28:671-5.

44. Abraham PA, Opsahl JA, Halstenson CE, Chremos AN, Matzke GR, Keane WF. The effect of famotidine on renal function in patients with renal insufficiency. Br J Clin Pharmacol 1987;24:385-9.

45. Knadler MP, Bergstrom RF, Callaghan JT, Rubin A. Nizatidine, an $\mathrm{H}_{2}$ blocker-its metabolism and disposition in man. Drug Metab Dispos 1986;14:175-82.

46. Naesdal J, Andersson T, Bodemar G, et al. Pharmacokinetics of omeprazole in patients with impaired renal function. Clin Pharmacol Ther 1986;40:344-51.

47. Howden CW, Reid JL. Omeprazole, a gastric proton pump inhibitor: Lack of effect on renal handling of electrolytes and urinary acidification. Eur J Clin Pharmacol 1984;26:639-40.

48. Koelz HR, Halter F. Sucralfate and ranitidine in the treatment of acute duodenal ulcer. Am J Med 1989;86(Suppl 6A):98-103.

49. Allain P, Mauras Y, Krari N, Duchier J, Cournot A, Larcheveque J. Plasma and urine aluminum concentrations in healthy subjects after administration of sucralfate. $\mathrm{Br}$ ] Clin Pharmacol 1990;29:391-5.

50. Robertson JA, Salusky IB, Norris KC, Coburn JW. Aluminum absorption in man, comparison of sucralfate and aluminum hydroxide. Kidney Int
1987;31:214.

51. Burgess ED, Muruve D, Audette R. Aluminum absorption and excretion following sucralfate therapy in chronic renal insufficiency. Am J Kidney Dis 1991; 17:A4

52. Leung ACT, Henderson IS, Halls DJ, Dobbie JW. Aluminum hydroxide versus sucralfate as a phosphate binder in uraemia. Br Med J 1983;286:1379-81.

53. Roxe DM, Mistovich M, Barch DH. Phosphate binding effects of sucralfate in patients with chronic renal failure. Am J Kidney Dis 1989;13:194-9.

54. Robertson JA, Salusky IB, Goodman WG, Norris KC, Coburn JW. Sucralfate intestinal aluminum absorption and aluminum toxicity in a patient on dialysis. Ann Intern Med 1989;111:179-81.

55. Campistol JM, Cases A, Botey A, Revert A. Acute aluminum encephalopathy in an uremic patient. Nephron 1989;51:103-6.

56. Burgess ED. Aluminum toxicity from oral sucralfate therapy. Nephron 1991;59:523-4.

57. Steiner JA. Misoprostol clinical pharmacology. Dig Dis Sci 1985;30(Suppl):136-41

58. Helander HF, Johansson C, Blan $\mathrm{H}$, Uribe A. Trophic actions of $E_{2}$ prostaglandins in the rat gastrointestinal mucosa. Gastroenterology 1985;89:1393-9.

59. Kauffman GL, Reeve JJ, Grossman MI. Gastric bicarbonate secretion: Effect of topical and intravenous 16,16-dimethyl prostaglandin $\mathrm{E}_{2}$. Am J Physiol 1980;239:644-8.

60. Leung FW, Robert A, Guth PH. Gastric mucosal blood flow in rats after administration of 16,16-dimethyl prostaglandin $\mathrm{E}_{2}$ at a cytoprotective dose. Gastroenterology $1985 ; 88 ; 1948-53$

61. Larsen KR, Jensen NF, Davis EK, Jensen JC, Moody FG. The cytoprotective effects of 15-deoxy16-hydroxy-16-methyl PGE, methyl ester(SC-29333) versus aspirin shock gastric ulceration in the dog. Prostaglandins 1981;21(Suppl):119-24

62. Chen MCY, Amirian DA, Toomey M, Sanders MJ, Soll AH. Prostanoid inhibition of canine parietal cells: Mediation by the inhibitory guanosine triphosphate binding protein of adenylate cyclase. Gastroenterology 1988;94:1121-9.

63. Horton R, Zipser R, Fichman M. Prostaglandins, renal function and vascular regulation. Med Clin North Am 1981;65:891-914.

64. Bauer RF. Misoprostol preclinical pharmacology. Dig Dis Sci 1985;30:S118-25. 
65. Agrawal NM, Saffouri B, Kruss DM, Callison DA, Djani EZ. Healing of benign gastric ulcer a placebocontrolled comparison of two dosage regimens of misoprostol, a synthetic analogue of prostaglandin E1. Dig Dis Sci 1985;30(Suppl): 164-70.

66. Graham DY, Agrawal NM, Roth SH. Prevention of NSAID-induced gastric ulcer with misoprostol: A multicentre double-blind, placebo controlled trial. Lancet 1988;ii:1277-80.

67. Aly A. Prostaglandins in clinical treatment of gastroduodenal mucosal lesions: A review. Scand J Gastroenterol 1987;137(Suppl):43-9.

68. Karim A. Antiulcer prostaglandin misoprostol: Single and multiple dose pharmacokinetic profile. Prostaglandins 1987;33(Suppl):40-50.

69. Nicholson PA, Karim A, Smith M. Pharmacokinetics of misoprostol in the elderly, in patients with renal failure, and when coadministered with NSAID or antipyrine, propranolol or diazepam. J Rheumatol 1990;17(Suppl 20):33-7.

70. Makowka L, Lopatin W, Gilas T, Phillips MJ, Falk R. Prevention of cyclosporine nephrotoxicity by synthetic prostaglandins. Clin Nephrol 1986;25:89-95.

71. Paller MS. Effects of the prostaglandin $E_{1}$ analogue misoprostol on cyclosporine nephrotoxicity. Transplantation 1988:45:1126-31.

72. Ryffel B, Donatsch P, Hiestand P,
Mihatsch MJ. PGE2 reduces nephrotoxicity and immunosuppression of cyclosporine in rats. Clin Nephrol 1986;25:95-9.

73. Strom TB, Carpenter CB. Prostaglandin as an effective anti-rejection therapy in rat renal allograft recipients. Transplantation 1983;35:279-81.

74. Moran M, Mozes MF, Maddox MS, et al. Prevention of acute graft rejection by the prostaglandin El analogue misoprostol in renal transplant recipients treated with cyclosporine and prednisone. N Engl J Med 1990;322:1183-8.

75. Hollander D, Tarnawski A. Are antacids cytoprotective? Gut 1989;30:145-7.

76. Slatopolsky E, Weerts C, Lopez-Hilker $\mathrm{S}$, et al. Calcium carbonate as a phosphate binder in patients with chronic renal failure undergoing dialysis. N Engl J Med 1986;315:157-61.

77. Anelli A, Brancaccio D, Damasso R, Padovese P, Gallieni M, Garella S. Substitution of calcium carbonate for aluminum hydroxide in patients on hemodialysis. Nephron 1989;52:125-32.

78. Alfrey AC, Terman DS, Brettschneider L, Simpson KM, Ogden DA. Hypermagnesemia after renal homotransplantation. Ann Intern Med 1970;73:367-71.
79. Randall RE, Cohen MD, Spray CC, Rossmeisl EC. Hypermagnesemia in renal failure. Ann Intern Med 1964;61:73-88.

80. Andreoli SP, Bergstein JM, Sherrard D]. Aluminum intoxication from aluminum containing phosphate binders in children with azotemia not undergoing dialysis. N Engl J Med 1984;310:1079-84.

81. Brahn M. Serum aluminum levels in non-dialyzed chronic uremic patients before and during treatment with aluminum containing phosphate binding gels. Clin Nephrol 1986;25:231-5.

82. Fauer JH, Rajfer J. Silicate urolithiasis. J Urol 1984;132:739-40.

83. Madias NE, Levey AS. Metabolic alkalosis due to absorption of "nonabsorbable" antacids. Am J Med 1983;74:155-8.

84. French JK, Holdaway IM, Williams LC. Milk-alkali syndrome following over-the-counter antacid self-medication. NZ Med ] 1986;99:322-3.

85. Schuman CA, Jones HW. The "milk-alkali" syndrome: Two case reports with discussion of pathogenesis. Q J Med 1985;55:119-26.

86. Moriniere P, Hocine C, Boudailliez B, et al. Long term efficiacy and safety of oral calcium as compared to $\mathrm{Al}(\mathrm{OH})_{3}$ as phosphate binders. Kidney Int 1989; 36(Suppl 27):S133-5. 


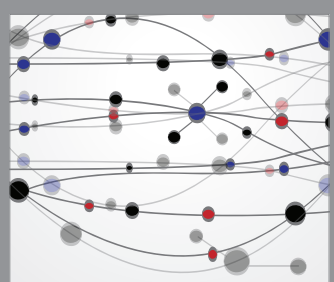

The Scientific World Journal
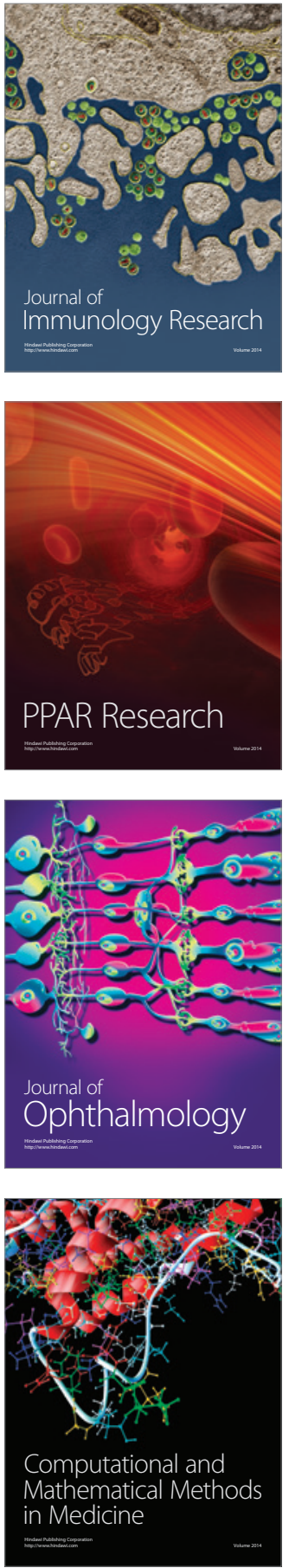

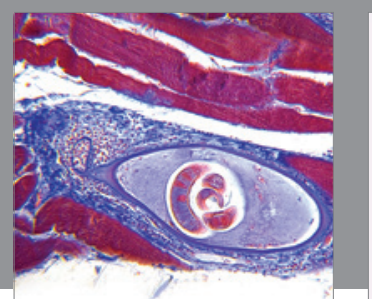

Gastroenterology Research and Practice

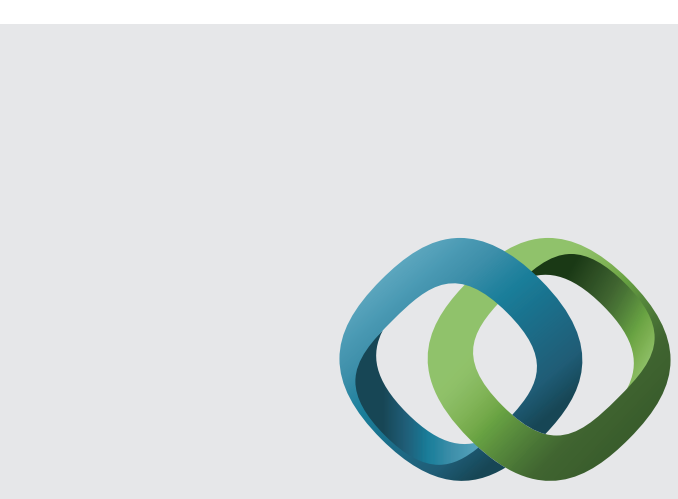

\section{Hindawi}

Submit your manuscripts at

http://www.hindawi.com
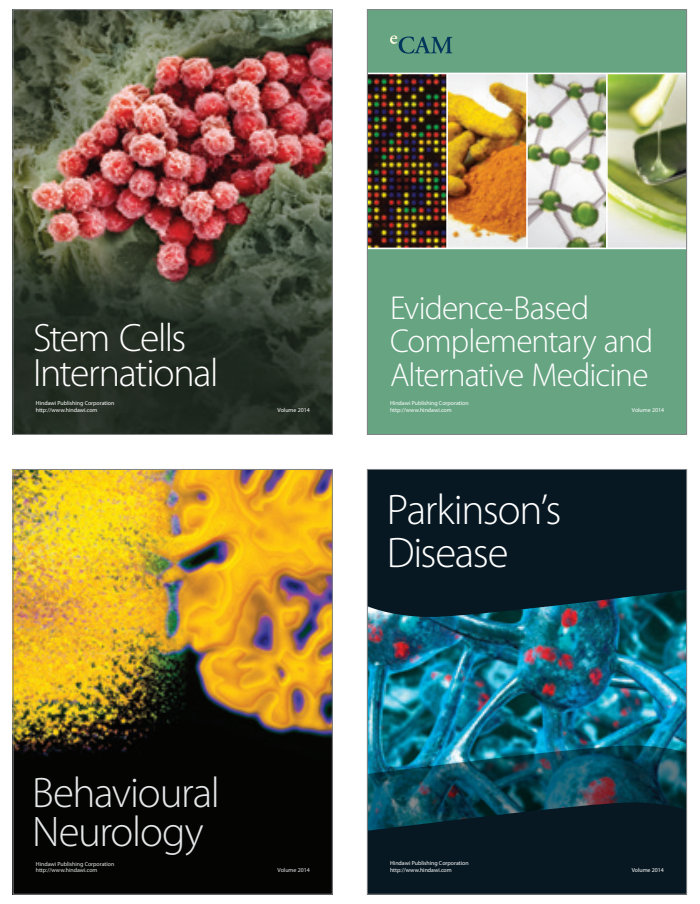
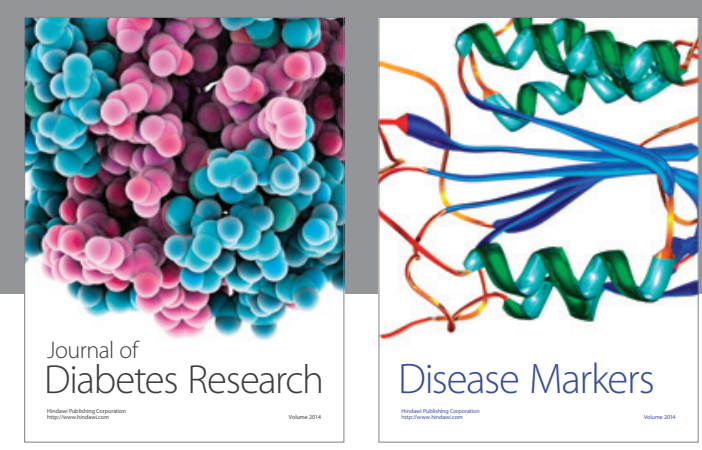

Disease Markers
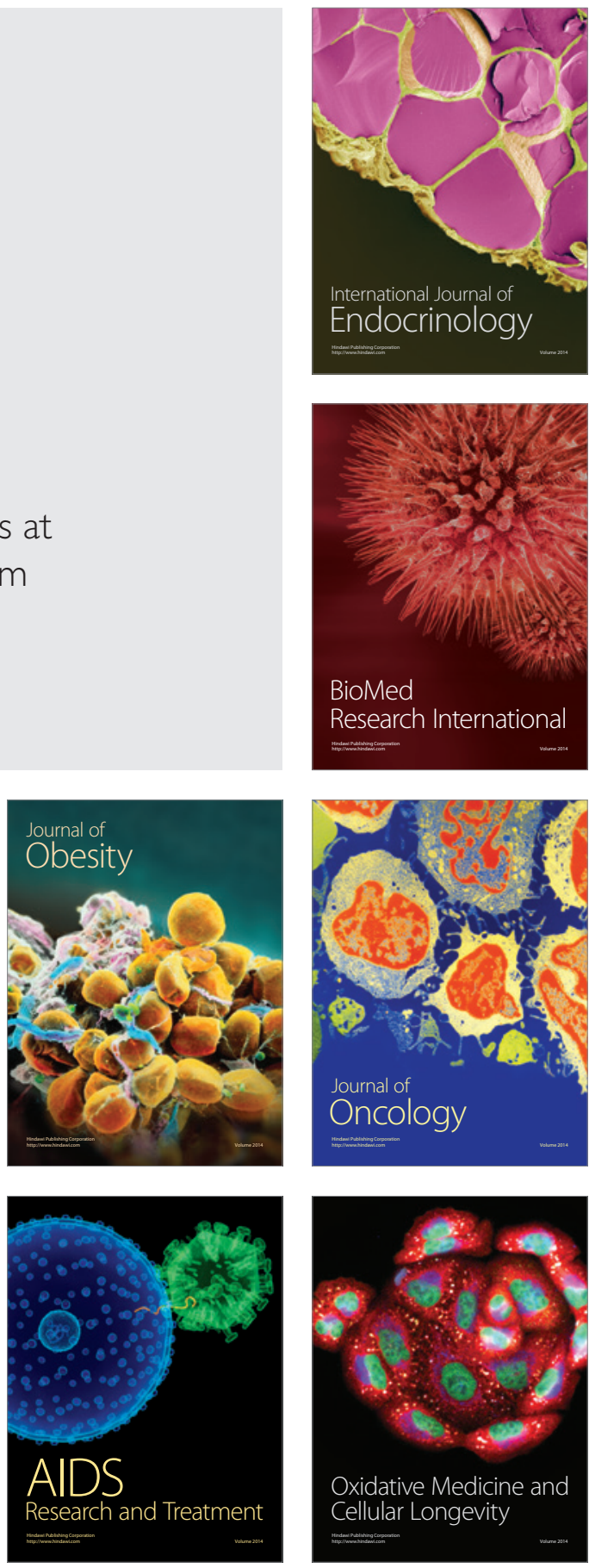